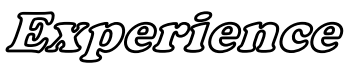

\section{The financial crisis and securitization}

\author{
Ewa Szabłowska \\ ewaszablowska@wp.pl
}

\begin{abstract}
Securitization means the change of non-liquid assets into securities. This topic has become more popular, mainly due to the U.S. subprime mortgage crisis. In this article, an analysis is given of the current situation in financial markets and the changes, which were implemented from the first days of subprime crisis. Also mentioned is the impact the crisis has had on securitization development.

Part of the article is devoted to the situation on the Polish financial market. It is quite a new market and it is susceptible to such crises. The Article presents the part played by securitization in the Polish financial market and the circumstances for its growth in the near future.

It also covers the latest information related to financial market regulations, which could have direct or indirect impact on the quantity and value of securitization transactions.
\end{abstract}

Keywords: securitization, financial crisis, subprime, Polish financial market.

\section{The genesis of the subprime mortgage crisis}

When speaking about the genesis of the subprime mortgage crisis it is best to go back to the 1920 's. The situation then in the property market was very similar to that which we have seen in recent years: a "boom" in the construction industry, the upward trend in property prices and good availability of mortgage credit (Campbell, Jerzemowska 2009). Rising prices of real estate and falling prices of mortgage loans helped to increase the debt of American society. A large part of the loans were refinanced and rolled over for further periods. This situation fed the whole mechanism of credit, until "the bubble burst". This is what occurred in the crisis of the 30's. Its consequences were (Thlon 2008):

- unemployment in the construction sector in excess of 2 million construction workers;

- a huge backlog of repayments of mortgage loans (more than half the borrowers had trouble repaying loans); 
- large variations in mortgage interest rates between the regions (in some parts of the country the credit market almost disappeared because it was not willing to purchase real estate mortgages);

- tightened the conditions for granting mortgage loans (loans for a maximum of $50 \%$ of property value).

A direct consequence of the Great Depression was the establishment of the Federal Housing Administration (FHA). The credit institutions Fannie Mae and Freddie Mac ${ }^{10}$ were the FHA's successors. These institutions were "the bridge" between the bond market, the lenders and the real estate owners. They amassed capital through the sale of bonds guaranteed by the government.

In the 1970's the innovative financial instruments MBS (Mortgage Backed Securities) appeared in the mortgage market (Reksa 2004). After some time, it started to be used it on a larger scale, it showed that the real estate market could gain trillions of dollars of additional capital. It gave the opportunity for rapid development of this economic sector.

In these times, the liabilities associated with the assessment of a credit risk started to get blurred, and already in the 90s more and more risky loans were granted, primarily for customers with low credit ratings. Gradually the requirements were reduced. The value of bad debts began to grow rapidly. Banks tempted potential borrowers with favorable conditions (grace periods for repayment of loans, promotional interest rates in the early years of credit) (DrewiczTułodziecka 2008, p. 2). Low interest rates and rising property prices encouraged people to increase borrowing. In addition, a large group of borrowers bought properties only for speculative reasons, believing that such an upturn in the property market would remain longer.

The situation started to deteriorate when the Federal Reserve repeatedly raised interest rates to stop inflation. The interest rate increases had a negative influence on the repayment value and the difficulties in new loans arose (particularly for the most risky households). In the initial phase, despite rising interest rates, debtors met their credit obligations. This situation changed when property appreciation stopped covering the increase in interest paid. When the fall in value of real estate began, subprime borrowers (especially those guided by speculative objectives) lost the ability to finance real estate, whose prices declined from day to day. The problems with repayment of subprime mortgages appeared (Kane 2009, p. 2). Nevertheless, banks continued to grant such loans. Only in 2006 people started to drew attention to the first signs of a crisis. Since March 2007, when New Century Financial

\footnotetext{
${ }^{10}$ More: www.fanniemae.com; www.freddiemac.com.
} 
Corporation - the largest American company announced its bankruptcy, other smaller companies in this industry began to collapse. These events exacerbated the situation on the real estate market. Falling demand for housing led to further declines in housing prices and thereby reduced the value of subprime mortgage securities. The fall in house prices contributed the growth rate of insolvency (Fender, Mitchell 2009, p. 27). Loan refinancing was more difficult or even, in some cases, impossible. By contrast, due to the decline in property value, banks, which had taken over properties from unreliable debtors were forced to sell occupied housing at a loss (Ruman 2007).

In March 2008 a series of bank insolvencies began. It was started by Bear Stearns Bank, which was acquired for a symbolic 2 U.S. dollars per share by JPMorgan Case. In September 2008 to talk of the bank collapse began. The largest institutions in the United States mortgage market - Fannie Mae and Freddie Mac - were taken over by the federal government. Also the 158 year old investment bank Lehman Brothers became bankrupt. The central banks tried to save the situation by putting 180 billion of emergency loans on the market.

In today's globalized financial markets, crisis in one market segment can quickly move to other segments. That was the case in the U.S. subprime crisis, which moved from America to Europe. Its first signs appeared in Europe in September 2007, when the British bank Northern Rock began to have financial problems. Six months later it was formally nationalized. In September 2008, the Benelux countries governments partially nationalized Fortis Bank, and the German government organized a multi-billion dollar rescue package for Hypo Real Estate Bank (Niklewicz 2008, p. 2).

Some financiers indicated that the main channel for the spread of the credit crisis was mortgage securitization. Below is presented the securitization mechanism.

\section{The concept and mechanism of securitization}

In its wider meaning securitization is seen as a way of resources flow between the units showing those in surplus and in deficiency (Gudkova 2002, p. 9). An entity will issue debt securities and offer them directly on the financial markets. This type of operation is called balance sheet securitization (primary, not structured).

In a narrower sense it is the process, in which a homogeneous group of non-liquid assets is separated off within the balance sheet, then the transfer of ownership or rights to reap the benefits from these assets is passed to a special purpose entity. This entity issues debt securities based on the transferred assets (Gudkova 2002, p. 10). This process is called Offbalance sheet securitization (secondary, structured) (Higgins, Mason, Mordel 2009). 
Thanks to the separation and transfer of risk securitization the efficiency of financial markets is increased and lower costs of financial services contribute to the stability of the financial system. It can be used as an instrument to finance acquisitions and mergers, construction of large-scale investments, highways and hotels. It is a good way to release regulatory capital. Improving the liquidity of assets is important, especially in banks.

Securitization can be applied not only to the assets, but also, in the case of banks, to liabilities: the opposite side of the balance sheet. In this way you can secure the liquidity of banks. Thanks to its properties, bank securities give the possibility to extend the deposit products offered with different maturities and profitability. They allow a better match with deposit liabilities due to active sources of financing (Cichorska 2000, p. 23-26).

The correct preparation and execution of securitization requires the cooperation of many units, such as asset sellers, investors, special purpose vehicles, insurers, rating agencies, administrators, swaps entities and other financial service providers. To accurately present the whole process, we should first look at the securitization object. Essential for the success of the operation is to prepare the appropriate assets pool (Reksa 2004a, p. 59-70).

The Securitization mechanism may vary depending on the conditions under which the process is carried out. This is because securitization is a flexible technique of financing, emerging under the influence of the transaction arrangers' priorities and the preferences of investors. This paper will present a simplified mechanism, which in practice can vary significantly. Differences may be due to the type of securitized assets, the objectives pursued by the originator of the process, as well as economic conditions and legal and cultural forces in the country.

The securitization process begins by isolating the arranger homogeneous package of financial assets from a pool of assets. The composition of the pool of assets should be adequately large and diversified. These assets can represent the right to payments occurring in the future or to claims which arise in the future. Usually at this stage a securitization team is created, which deals with the analysis of documentation relating to assets held for securitization, defining the parameters of the transaction and discussing the benefits and costs of securitization. The team may include representatives from departments such as auditing and internal controls, credit policy, treasury, IT systems, legal.

Then the special enterprise, fund or other entity with district legal and organizational responsibilities is set up. In the literature this entity is called the Special Purpose Vehicle (SPV). The arranger sells the separated assets to this entity. To pay for the purchased receivables, SPV issues debt securities such as bonds, commercial papers, stock certificates 
and sells them on the public market, or directly to institutional investors. These securities are known as Assets Backed Securities (ABS).

Usually ABS are assessed by credit rating agencies (e.g. Standard, Poor's, Moody's 2009). This raises the cost of capital, but nevertheless it is often used. The higher the rating, the lower the rate of return demanded by investors. Therefore, if the assets have good quality and/or the sufficient security is provided, the cost of funding is reduced (Kosiński 1997, p. 13).

In the next stage of the securitization process, ABS-s are offered to investors. Money from the purchasers of the securities is transferred to SPV, which will then forward it to the arranger of the transaction. Committed capital and interests are returned to investors from the earnings related to accounts receivables. This phase is executed via the SPV. The maturity date of securities issued in the securitization should be related to the maturity of the assets pledged as security (Puterko, Puterko 2002, p. C4). Often there is also an appointed service agent (servicer) - usually the arranger, whose task it is to handle receipts from debtors. Those who wish to spice up offers apply additional safeguards related to the repayment of the securitized receivables (credit and liquidity enhancement). In the case of occurrence of events stored in the contract, such as delayed or non-payment of a specified proportion of claims, the guarantor provides the money to meet the investors claims (Kosiński 1997, p. 13).

Chart 1. Securitization process

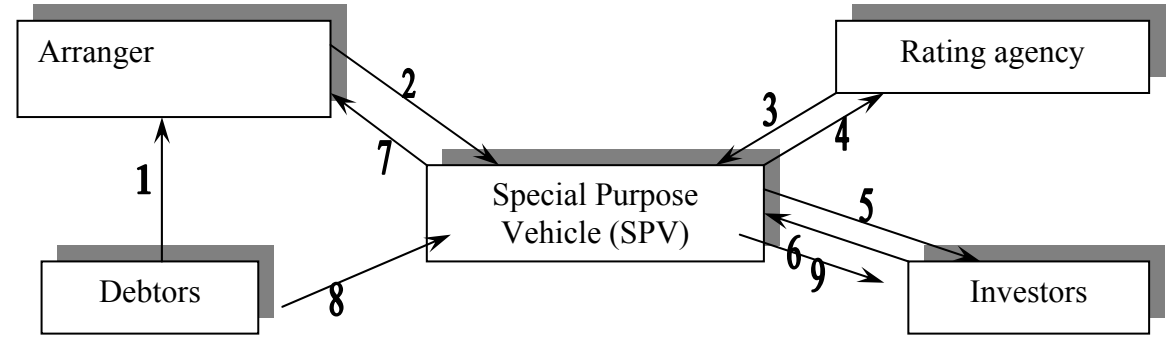

1- debtors commitment e.g. mortgage

2 - trade assets

3 - rating for the securities

4 - rating agency fee

$5-$ MBS issue

Source: Author
6 - earnings from MBS issue

7 - funds for arranger related to trade assets

8 - repayment by debtors

9 - capital and interest's repayment (related to MBS) 


\section{The role of securitization in the subprime crisis}

The current crisis has shown that the securitization of banks' assets generates certain situations in inverse relation to what is pursued. However, we should not blame it for all the "evil" associated with the crisis. It played only an indirect role in the current crisis.

The main cause of the crisis in the U.S. was lenders focusing on the securities of credit rather than the financial situation of borrowers. In addition, we can also mention the wrong assessment of collateral value. Banks forecast, that the upturn in the property market would not change in the coming years, and thus the real estate which secured loans would even gain more value. But as it turned out, this perception was wrong. Collateral accepted by banks in the form of real estate began to lose value. Increasing supply of real estate and declining demand for it was the main reason for this situation.

Other factors, which indirectly contributed to the crisis were:

- no credit insurance obligation,

- risky repayment options - defer payment of capital installment, promotional interest rates for the first 2-3 years,

- variable interest.

Lenders did not take into account a large-scale increase in interest rates on loans and increasing cost of living for debtors (including a significant increase in energy prices). Currently, many debtors were not even able to pay interest based on the initial interest rates. In addition, liberal credit policy, credit stealing and bypassing procedures - all of them increased rate of insolvency (Małysz 2008b, p. 4).

In its traditional role the lending bank takes the credit risk associated with the insolvency of the debtor. Currently, this is no longer so obvious. In the securitization process, the risks related to borrower's insolvency have been moved to many different participants. Now loans and payments for mortgage loans could be treated as a collateral for a number of structured securities. It was a common way of funding the mortgage portfolio in the U.S. The increase in delays in subprime mortgage repayments has caused sale of these instruments and investors retreat, which in turn caused the liquidity problems for many banks. This stage of the crisis was the most commented on and here the negative role of securitization was emphasized (Małysz 2008b, p. 5).

The main problem is not only the insolvency of securities backed by mortgage, but the uncertainty related to ignorance about institutions and how much they are involved in this market. Securitization as a method of financing should not be seen as the main source of risk. 
Choice of bad assets for the securitization process may increase the risk of the transaction. Regular receivables securitization does not increase risk. Transaction risk increases when we choose threatened receivables and we should be prepared for the growth of insolvency rate. The investors agree on a higher risk, but they demand a higher price for their financial resources.

Transparency throughout the process of securitization is another factor contributing to the increase in risk. A simple clear structure of the process is most desired by the participants. But in reality we are dealing with many types of securitization, where the level of complexity is very high. In addition, the legal situation is not always clearly defined, it may cause discrepancies in interpretation. The more complex the process, the greater the risk of irregularity.

Lack of information or difficult access for participants, may result unconsciously in higher risk. Typically, such a situation occurs in growing financial markets, where we have a lack of credit history (this is the case in Poland).

\section{Echos of the subprime crisis on the Polish financial market}

The Polish mortgage market is relatively new, and in the early stages of development. The ratio of mortgage loans to GDP is around $10 \%$, while the EU average is around $50 \%$, and the U.S. about 75\% (Pawłowicz 2007). Our market is not directly linked to the international mortgage market. It has a national character.

The Polish mortgage market has a short credit history. Most of the scoring models were built based on the internal data. Taking into consideration that during the first two years of the mortgage loan likely delays in repayment are relatively small, and increasing levels of insolvency occur within three to five years of the loan, Polish models based on relatively poor data can lead to internal underestimation of credit risk. Banks with parent companies may benefit from the experience of the group, but we should not forget to adjust the solutions to Polish conditions.

Several years of property values growth caused a general recognition among the lenders to increase the property value in the future (same situation as in the U.S.). In addition, the bulk of mortgage loans in Poland are indexed by market interest rates. In this situation, increase in interest rates may cause problems with the access to new loans. The consequence of such difficulties may be a decrease in demand in the housing market and, thus, decrease of property values. Coincident increase in interest expenses can increase the rate of debtor 
insolvency. High real estate supply and a reduced demand, may lead to a decline in value. At this point, there could appear the same situation as we had in the U.S. (Małysz 2008a, p. 3).

Within the loans granted by Polish banks we can find e.g.:

- loans with LTV ratio of $130 \%$ (without own contribution);

- loans for customers with low income for a period of 50 years;

- mortgage loans denominated in foreign currencies (over $50 \%$ of all mortgages) - The Swiss franc is the dominant currency, increased debt servicing costs can be expected in the case of a weakening Polish zloty (borrowers usually evaluate their debt repayment capacity based on the current volume of interest, without taking into account the potential decline in the value of the zloty);

- most of the mortgages are indexed by market rates - it increases the risk of crisis in case of a foreign crisis transfer (this may cause a retreat from emerging markets, the zloty may lose value).

On the Polish market we can also find now loans for people who do not receive loans according to standard procedure (i.e. subprime loans). These are individual deals, but they should not be ignored in the analysis of credit market. At the time of the spread of this loan type, the risk of the subprime crisis in Poland becomes real (www.eHipoteka.com, www.ehipoteka.com.pl).

The Polish market for credit derivatives linked to securitization has a marginal share in the Polish financial market. Units are reluctant to engage in securitization transactions. The lack of mortgage securitization on our market may be a good proof of it (Pawłowicz 2008, p. 4). Therefore, securitization does not cause direct consequences on the Polish credit market. Moreover, the degree of Polish companies involvement in foreign instrument investments in the securitization markets is insignificant. Investors are very careful in terms of investments in the securities backed by mortgages.

The big threat to the stability of the Polish financial sector is the mechanism of credit expansion, similar to mechanisms in countries which are now affected by the credit crunch. It can spiral out of control and lead to a crisis. This mechanism is now under the control of supervisory institutions. So far they have not taken significant steps since we were in the initial phase of the expansion of mortgage credit. Their tasks are limited to prevention.

The declines in the Polish stock market were indirect consequences of the U.S. credit crisis (Boniecka 2007). Investors, encouraged by high rates of profits, paid their savings into funds and did not expect any crisis. When foreign investors heard about the U.S. crisis, they 
began to withdraw capital from our country. They wanted to protect the investments in their home countries. It was an alarming signal for Polish investors. They also began to withdraw their money. The large supply and declining demand for units in the funds resulted in decreases in the prices of those units. However, this situation was more psychological than market based. The investors concerns about their own capital were the driving force behind the price decreases.

Although the American crisis did not affect our market directly, we should be prepared for higher interest rates for mortgage loans. The reason for this it is the increase in the price of money on international markets. Poland, a country classified as a emerging market, may be forced to pay higher margins in terms of market maelstroms. Currently, the interbank market players have a more reserved approach to lending.

We can now observe some subprime crisis influence on the Polish real estate market. The upward trend in house prices has stopped and the real estate liquidity decreased. Banks began to record the growth of claims in the mortgage segment. So far, we have had high liquidity in the Polish banking system, but now we can observe more an intensive search for financing in the market (e.g. by increasing the attractiveness of deposits). In addition, the cost of living in Poland is increasing, which consequently leads to an increase in interest rates.

The reduction of the stock exchange role in the financing of business investment is another consequence of the crisis on the U.S. market. However, in Polish conditions, we do not need to fear it, as the part played by stock exchange in the financing of business investments is very small. In 2006-2007, the ratio of share issue to the value of total investment was only 4\% (Petru 2007).

The problems of Polish banks ' parent companies may indirectly affect the situation on the Polish market. The losses incurred by the parent company on the subprime market, may lead to reduction of the financing of the subsidiary in Poland. Polish banks, strategic investors are major players in the home market, and thus the risk of bankruptcy of the bank's parent Polish banks should be considered as a very small (Kluza 2008).

The Polish investors loss of interest in sophisticated credit instruments can be perceived as an additional effect of U.S. subprime crisis.

The current situation in Poland, indicates a lack of direct factors that could lead to a move of the U.S. mortgage crisis on our market. The proofs for such situation are (Ruman 2007):

- strict lending rules - in the U.S. there was a liberal credit policy, which caused credit frauds and procedure avoidance; 
- market for subprime mortgages almost non-existent;

- lack of consumer bankruptcy act - it is in the U.S. and also in some European countries, it caused difficulties for banks to recover money from outstanding loans;

- debt of Polish society is still many times lower than in American society or in the population of Western Europe;

- Polish entities generally do not invest in U.S. securities backed on subprime loans;

- bank credit portfolios are not financed through securitization.

\section{Changes in Polish legislation related to securitization}

Currently in Poland, there are a lot of discussions about changes in the financial market regulations. All seek to strike a balance to avoid a credit crunch. No binding decisions have been made. The discussions are ongoing and new projects are appearing.

According to the new legislation, guarantees on bank deposits have been doubled, and relate to all contributions. There are also greater possibilities of obtaining state guarantee of repayment of borrowings from other banks. This is to guard the banks through the crisis of confidence and help them to raise funds for activities in the interbank market.

The Polish Parliament adopted a law on supporting financial institutions. The Treasury will be able to give financial support to banks, investment funds and insurers (established in Poland) which are at risk of liquidity loss.

The Polish National Bank has introduced a package of solutions designed to improve the liquidity of banks. Thanks to these rules, banks gained greater access to the so-called patyn loan ${ }^{11}$. Moreover, PNB pulled from the Swiss central bank a loan in Swiss francs and supported Polish banks in exchange for the euro (the currency swaps) (Samcik, Skwirowski, 2008, p. 3).

We should also not forget Recommendation S. It includes elements aimed at reducing the risk of a credit crisis in the Polish market. Recommendation $\mathrm{S}$ requires conducting stress tests, which will take into account the increase in interest rates, the depreciation of the value of the zloty, the decline in house prices and difficulties in the interbank market liquidity.

Beside transactional models and construction of models for IRB method purposes the largest banks are required to regularly review their internal capital models. This is particularly important in the case of mortgage loans portfolios, where the historical data used to build internal models may be inadequate in the current situation (Małysz 2008a, p. 4).

\footnotetext{
${ }^{11}$ It is the granting of credit to the commercial banks by National Bank of Poland against the securities.
} 


\section{Conclusions}

Globalization has increased the frequency and rate of spread of financial crises. Inability to use the modern financial engineering instruments, mainly poor use of securitization in the process of obtaining financing, led to a crisis moving to areas not related directly to the credit market.

Securitization of subprime loans probably will not result in direct consequences for the Polish financial market. This does not mean that there are no indirect consequences of perturbations in global financial markets and stemming of the rate of growth of the world economy, including a number of EU economies.

\section{Bibliography:}

Campbell K., Jerzemowska M. (2009), The 2008/9 Global Financial Crisis in Perspective: Financial Bubbles and other Factors, [in:] Zarzecki D. (ed.), Emerging Market Economies as FDI Host Countries During the Financial and Economic Crisis, "Zeszyt Naukowy Uniwersytetu Szczecińskiego” No. 533, Uniwersytet Szczecinski, Szczecin. Cichorska J. (2000), Sekurytyzacja depozytów, ”Bank”, No. 4/ April.

Drewicz-Tułodziecka A. (2008), Ocena ewentualnych analogii i skutków kryzysu subprime w USA na polskim rynku kredytów hipotecznych, Fundacja na Rzecz Kredytu Hipotecznego, Warszawa.

Fender I., Mitchell J. (2009), The future of securitisation: how to align incentives? „BIS Quarterly Review", No. 3/ September.

Gudkova S. (2002), Sekurytyzacja należności kredytowych banków, Wydawnictwo Wyższej Szkoły Przedsiębiorczości i Zarządzania im. Leona Koźmińskiego, Warszawa.

Higgins, E.J., Mason, J.R., Mordel A. (2009), Asset Sales, Recourse, and Investor Reactions to Initial Securitizations: Evidence why Off-balance Sheet Accounting Treatment does not Remove On-balance Sheet Financial Risk, "Working Paper Series", 22.05.2009.

Kane E.J. (2009), Incentive roots of the securitization crisis and its early mismanagement, “CEPR Policy Insight”, No. 32/ March.

Kluza S. (2008), Sytuacja sektora bankowego w 2007 r., "Materiały z Forum Bankowego 2008”, Związek Banków Polskich, Warszawa.

Kosiński A. (1997), Sekurytyzacja aktywów na świecie $i$ w Polsce, Biblioteka Menadżera i Bankowca, Warszawa.

Małysz R. (2008b), Powtórka z USA?, "Gazeta Bankowa", No. 14/ March. 
Niklewicz K. (2008), Kalendarium zapaści, ”Gazeta Wyborcza”, 9.10.2008.

Pawłowicz L. (2008), Polska wobec wyzwań kryzysu finansowego, Instytut Badań nad Gospodarką Narodową, Gdańsk.

Puterko K. Puterko I. (2002), Sekurytyzacja po polsku. Tańsze dużym kosztem, "Rzeczpospolita", 11.03.2002.

Reksa, Ł. (2004a), Sekurytyzacja wierzytelności na rynkach międzynarodowych, "Bank i Kredyt", No. 2/ February.

Reksa, Ł. (2004b), Szuflady sekurytyzacji, ”Gazeta Bankowa”, No. 1/ January.

Samcik, M., Skwirowski, P., Sudak, I. (2008), Co rzqd i NBP robia, by nie dopuścić do kryzysu w Polsce... , "Gazeta Wyborcza", 23.11.2008.

Petru, R., Subprime a sfera realna gospodarki (2007), „Nawigator”, Biuletyn Banku BPH, 12.09.2007.

Thlon M. (2008), Krótka historia amerykańskiego rynku kredytów hipotecznych - czyli jak ewaluowat American Dream (cz.1), „Rzeczpospolita”, 23.10.2008.

Netography:

Boniecka, A. (2007), Giełdowe wibracje 2007 roku, www.bankier.pl/wiadomosc/Gieldowe-wibracje-2007-roku-1689511.html, retrieved: 27.12.2007.

Małysz R. (2008a), Echa kryzysu na rynku hipotecznym, www.bankier.pl/wiadomosc/Echakryzysu-na-rynku-hipotecznym-1739657.html, retrieved: 03.04.2008.

Pawłowicz, L. (2007), Kryzys na amerykańskim rynku kredytów hipotecznych - lekcja dla Polski, www.bankier.pl/wiadomosc/Kryzys-na-amerykanskim-rynku-kredytow-hipotecznychlekcja-dla-Polski-1680382.html, retrieved: 7.12.2007.

Ruman Sz. (2007), Groźny kryzys, www.polskieradio.pl/publicystyka/artykul.aspx?id=23968, retrieved: 15.11.2007.

www.ehipoteka.com.pl/index/?id=158f3069a435b314a80bdcb024f8e422.

www.fanniemae.com.

www.freddiemac.com. 